\title{
Chronic Carriers of Hepatitis B Surface Antigen in an Endemic Area for Schistosomiasis Mansoni in Brazil
}

\author{
JC Serufo/+ , CMF Antunes*, RA Pinto-Silva, R Gerspacher-Lara, AAM Rayes, \\ SC Drummond**, CMF Reis, MJ Martins, SA Mingoti***, JR Lambertucci
}

\author{
Departamento de Clínica Médica, Faculdade de Medicina, UFMG, Av. Alfredo Balena 190, 30130-100 Belo \\ Horizonte, MG, Brasil *Departamento de Parasitologia, Instituto de Ciências Biológicas, UFMG **Fundação \\ Nacional de Saúde ***Departamento de Estatística, ICEX, UFMG, Belo Horizonte, MG, Brasil
}

Data on the association of schistosomiasis and hepatitis B in field-based studies are scarce. Two areas have been selected for this study: i) Queixadinha, endemic for schistosomiasis, with a population of 693 individuals, and ii) Capão, a control non-endemic area, with 515 inhabitants. Sera of all individuals in both areas were tested for hepatitis B infection, yearly, from 1994 to 1997. In the first area hepatitis B was found in $32.1 \%$ of children up to one year old and reached a peak of $68.7 \%$ in the age range of 15 to 19 years. In the control area the prevalence of hepatitis B was under $5 \%$ up to 19 years of age and the highest prevalence was observed in adults over 45. HBsAg was detected in $9.4 \%$ of the individuals living in the endemic area for schistosomiasis and in $1.4 \%$ of the controls $(O R=4.98$; 95\% CI=3.7-6.7). The index of chronicity of HBsAg was not statistically different in the studied areas $(8.1 \% \times 7.3 \% ; O R=1.09 ; 95 \% C I=0.42-3.03)$, nor was it different for people with and without schistosomiasis in Queixadinha (8.7\% x 7.0\%). We conclude that the Schistosoma mansoni infection has not altered the course of hepatitis $B$ in the studied area.

Key words: Schistosoma mansoni - hepatitis B - chronic hepatitis B - HbsAg carriers

Data on the association of Schistosoma mansoni infection and hepatitis B virus (HBV) in endemic areas are rather few. In hospital-based series, the carrier rate of $\mathrm{HBV}$ in patients with hepatosplenic schistosomiasis was higher than in the controls (Guimarães 1973, El-Raziky et al. 1979, Guimarães et al. 1981, El-Badrawy et al. 1983, Hammad et al. 1990, Ghaffar et al. 1991, Farghaly \& Barakat 1992, Darwish et al. 1992), whilst in field-based studies controversy on the strength of the association still remains (Bassily et al. 1979, Hyams et al. 1986, Eltoum et al. 1991).

Some authors have suggested that infection with the hepatitis B virus in patients with schistosomiasis tend to evolve more frequently to chronicity and may also induce a more severe form of schistosomiasis (Lyra et al. 1976, Bassily et al. 1983, Hunter et al. 1983, Daneshmend et al. 1984, Coelho et al. 1985, Van der Borch 1987, Pereira et al. 1994).

\footnotetext{
This work was partially supported by CNPq, Capes and National Health Foundation (Brazil).

${ }^{+}$Corresponding author. Fax: +55-31-241.6402. E-mail: lamber@net.em.com.br

Received 4 May 1998

Accepted 31 August 1998
}

In previous works a series of hindrances have impaired a convincing statistical analysis of data. The problems included miscalculation of sample sizes in the majority, the absence of control groups or the inadequate selection of groups and/or major losses of patients during follow up in some, and the low accuracy of old laboratory tests used to diagnose hepatitis B in studies made in the seventies (Serufo \& Lambertucci 1997, Serufo 1997).

This is the first field-based study on the association of hepatitis B and schistosomiasis in Brazil in which the index of chronicity for hepatitis B was compared in endemic and nonendemic areas. We conclude that schistosomiasis did not alter the course of hepatitis B in a rural community of Brazil.

\section{MATERIALS AND METHODS}

Study area - Two areas have been selected for this study: i) Queixadinha, a rural community in the district of Caraí, in the northeast of the State of Minas Gerais, Brazil (Lambertucci et al. 1996), lies in an area known to be highly endemic for schistosomiasis mansoni, and ii) Capão, also a rural community in the district of Presidente Juscelino in the northwest of the same state, where schistosomiasis has never been found. No case of malaria, acute Chagas disease or visceral leishmaniasis has been diagnosed in both areas in recent years. Although 
these two communities are located $350 \mathrm{~km}$ apart, they present similar social, economic and hygiene conditions.

Subjects - A census was made and 693 individuals of Queixadinha ( $92.8 \%$ of the total population (mean age 22.9 , range $0-86 ; 51.2 \%$ females, $48.8 \%$ males) and 515 individuals of Capão (95.9\% of the total population, mean age 28.2, range 0-83; $48.5 \%$ females, $51.5 \%$ males) underwent clinical, and ultrasonographic examination and laboratory tests following a standard protocol. All had 2-4 stool examinations by the Kato-Katz technique (Katz et al. 1972); the prevalence of $S$. mansoni infection in Queixadinha was $66 \%$ based on two stool examinations, and only one patient in Capão was found eliminating eggs of the worm in the stools (he almost certainly acquired the infection in another district). Patients with schistosomiasis were classified into two groups: hepatointestinal (eggs in the stools with or without periportal fibrosis) and hepatosplenic (eggs in the stools, splenomegaly on palpation or/and severe periportal fibrosis on ultrasound) (Lambertucci 1993). Informed consent was obtained from the patients for this study and the protocol has been reviewed and approved by the Ethical Committee of the Faculty of Medicine, Federal University of Minas Gerais.

Ultrasonography - All individuals older than 5 years were submitted to abdominal ultrasonography using real-time equipment with Hitachi EUB200 electronic linear 3.5 MHz transducers; the inner diameter of the portal vessels and the thickness of the vessels and the gall-bladder wall were measured. Periportal fibrosis and splenomegaly were defined according to the standard protocols of the World Health Organization (WHO 1991), as adapted by others (Rosenberg et al. 1991, PintoSilva et al. 1994, Gerspacher-Lara et al. 1997).

Serological diagnosis of hepatitis $B$ and definitions - Blood samples were obtained of all individuals in both areas, yearly, from 1994 to 1997. Sera were tested for the following hepatitis B markers: hepatitis B surface antigen (HBsAg), antiHBsAg and anti-HBcAg using the enzyme immunoassay kit for HBV (Hepanostika, Organon Teknika, Boxtel, Holland). Hepatitis B has been studied admitting four definitions: (1) Hepatitis B: individuals showing any positive serological marker of hepatitis B; (2) HBsAg positives: those who tested positive for hepatitis B surface antigen in the first exam; (3) HBsAg carriers: those who tested positive two times for HBsAg with one year of interval; (4) Index of chronicity: the frequency of HBsAg carriers among those with any positive serological marker of hepatitis B.

In both areas no history of exposure to the transfusion of blood or blood products was obtained.
All individuals denied the use of intravenous illicit drugs or acupuncture. Besides, no tattoo marks were found during clinical examination.

Data analysis - Statistical tests (chi-square, ANOVA and Student's t) for comparison of proportions and means were performed with aid of Epiinfo version 6 software (Dean et al. 1990). The statistical significance of the results was tested at a $5 \%$ level. ROC (receiver operating characteristic) curves were built to compare ultrasonographic data in patients with and without hepatitis B (Hanley \& McNeill 1990). Multivariable logistic regression analysis was used to adjust for confounders (Norusis 1992). A hierarchical Cluster Analysis was used to identify possible clustering among cases of hepatitis B. The Average and Single linkage methods were used for grouping the data. The Euclidean distance was used as a similarity measure (Johnson \& Wichern 1992).

\section{RESULTS}

The prevalence of schistosomiasis, the worm burden and the serological markers of hepatitis B in each age group are depicted in the Fig. 1. In Queixadinha, serological markers of hepatitis B were found in $32.1 \%$ of children up to one year old and reached a peak of $68.7 \%$ in the age range of 15 to 19 years. In the control area the prevalence of serological markers was under $5 \%$ up to 19 years of age and the highest prevalence was observed in adults over 45 .

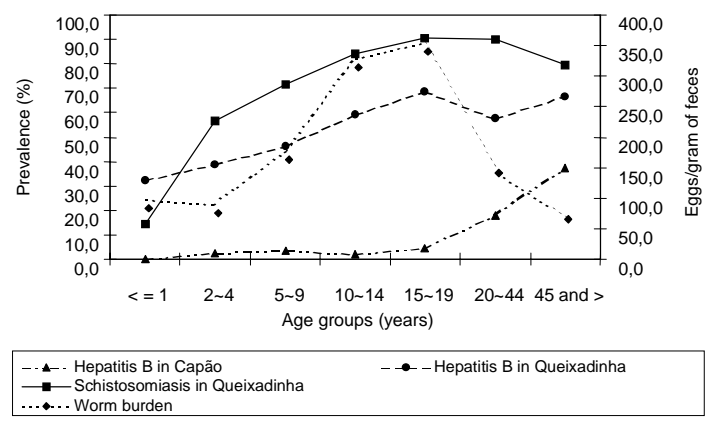

Fig. 1: prevalence of schistosomiasis, worm burden and hepatitis B in each age group in the studied areas.

HBsAg was detected in $9.4 \%$ of the individuals living in the endemic area for schistosomiasis and in $1.4 \%$ of the individuals in the control area $(\mathrm{OR}=4.98 ; \mathrm{CI}=3.7-6.7)$. The prevalence of chronic carriers of HBsAg was higher in the endemic area for schistosomiasis: 31 out of 605 individuals $(5.1 \%)$ in Queixadinha were chronic carriers of HBsAg against 6 out of 499 (1.2\%) in Capão $(\mathrm{OR}=4.41 ; 95 \% \mathrm{CI} 1.74-11.85)$. However, in the endemic area for schistosomiasis no difference in 
the prevalence of chronic carriers of HBsAg was found in people with or without schistosomiasis $(8.7 \%$ x $7.0 \%)$. The index of chronicity of HBsAg was not statistically different in the studied areas $(8.1 \% \times 7.3 \%$; OR=1.09; $95 \% \mathrm{CI}=0.42-3.03)$.

There was a homogeneous distribution of schistosomiasis in Queixadinha whereas the distribution of hepatitis B, in the same area, occurred in familial clusters.

There was a significant grouping among the cases of chronic carriers of hepatitis B in Queixadinha in all areas studied. A typical dendogram of the cluster procedure is shown in Fig. 2. Area 27 was considered in two levels of similarity: at the similarity level of $90 \%$ the dendogram indicates the existence of four groups $\{1\}\{2,3,4,5\}\{6,7\}\{8\}$; at a level of $70 \%$ the individuals could be partitioned in only two groups as $\{1,2,3,4,5\}$ and $\{6.7 .8\}$.

Parameters of morbidity, such as hepatomegaly, splenomegaly, worm burden (number of eggs in the stools), periportal fibrosis, portal vein diameter and thickness of the vessels and of the gallbladder wall measured by ultrasonography were evaluated in regard to the presence or absence of serological markers of hepatitis $B$. No variable studied correlated in any way with hepatitis B. No confounders were identified in the multivariate analysis.

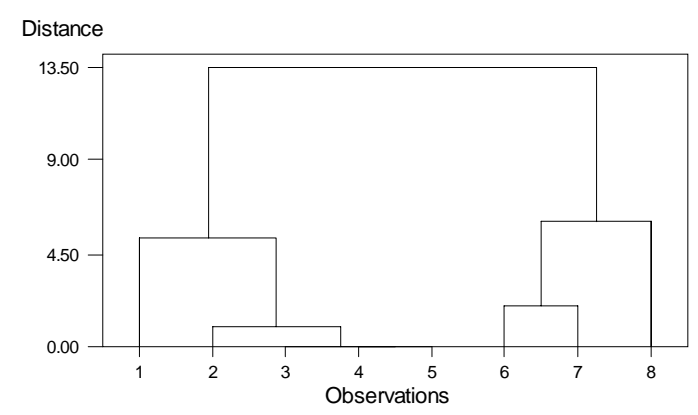

Fig. 2: dendogram of the cluster analysis performed for the chronic carriers of hepatitis B cases observed in the area 27 of Queixadinha using the Average linkage method.

\section{DISCUSSION}

The prevalence of chronic carriers of HBsAg was higher in the endemic area for schistosomiasis and examinig for the first time the data summarized in Fig. 1 one gets the impression that there is a correlation between egg burden and the prevalence of hepatitis B in most age groups. A more closer look, using multivariate regression analysis, though, demonstrated the absence of association betweeen HBV infection and the intensity of
S. mansoni infection. This is consistent with some previous field-based studies (Domingo et al. 1983, Eltoum et al. 1991).

The prevalence of chronic carriers of $\mathrm{HBsAg}$ was similar for people with or without schistosomiasis in the endemic area. The index of chronicity for hepatitis B infection was not different in both areas (endemic or non-endemic) showing that schistosomiasis did not change the course of hepatitis B in the endemic area studied.

Clinical and ultrasonographic markers of morbidity were not associated with hepatitis B virus infection. The history of bleeding from esofageal varices in the endemic area was not frequent and most individuals with hepatosplenomegaly and periportal fibrosis looked healthy. It has been suggested that the sickest move to big cities where they receive the necessary attention they need (i.e., surgery for portal hypertension, and/or endoscopic sclerotherapy of esofageal varices) and also expose themselves to medical manipulation and blood transfusion that increase their chances of being infected with the hepatitis B virus (Strauss et al. 1988). Therefore, the population examined in this study is quite different from the one described in the wards of general hospitals. Moreover, the populations studied did not present the usual risks for hepatitis B described for urban areas (parenteral treatment, dental manipulations, tattoing) and transmission of hepatitis was probably from mother-tochild, child-to-child and by sexual intercourse (Leichtner et al. 1981, Coltorti et al. 1984, Franks et al. 1989, Hurie et al. 1992). Other markers for sexually transmitted diseases such as FTA-abs (performed in randomly selected sera of 250 individuals of each area) resulted negative (Serufo 1997).

This study showed that in an endemic area there was no association between the HBsAg carrier state and schistosomiasis, with or without periportal fibrosis.

The results have shown that there was a significant grouping among the cases of chronic carriers of hepatitis B in Queixadinha. The final number of clusters for each area was chosen according to the similarity level. For most of the areas a $90 \%$ similarity level was used. An exploratory analysis of the final clusters for each area has indicated that the variables related to geographical proximity of the cases were more determinant in forming the groups. Considering that in the specific case of Queixadinha geographical proximity also indicates blood relative relationship among the cases, it could be concluded that a family factor has influenced the grouping of the cases.

The State of Minas Gerais has been defined by the Ministry of Health as an area of low prevalence of hepatitis B infection and this view is de- 
rived mostly from surveys made using the sera of blood bank donors (Zuckerman 1985, CNE/FNS/ MS 1996, Serufo et al. 1996). In this study the high prevalence of hepatitis B in Queixadinha (9.4\% for HBsAg marker) calls for a reevaluation of the vaccination policy for hepatitis B defined for the State. In areas like Queixadinha vaccination for hepatitis $B$ must be adopted without delay.

\section{ACKNOWLEDGEMENTS}

To Benedita Braz Siqueira, Andréia de Fátima Barbosa Pires, Simone Gonçalves dos Santos, Reinaldo Vieira Rosa, José Carlos Serufo Filho, Angela Serufo, Carla Serufo, Neide Fernandes de Castro, Ludgério Rodrigues Neto, José Maria Bernardes and Silvana Romano da Silva for technical support and Dr Rosângela Teixeira for helping in the clinical examination of patients. To the Organon Teknika for providing the ELISA kits to test the sera for hepatitis B markers and the Micra Biotechnology Laboratory for carrying out the serological tests.

Note: while the present paper was being analyzed by the referees of the Mem Inst Oswaldo Cruz, Dr Tavares Neto had the summary of his thesis (Livre Docência) on hepatitis B and schistosomiasis published in the Rev Soc Bras Med Trop 31: 411-413, 1998. In his thesis Dr Tavares Neto did not find an association between the presence of hepatits B and C markers and the hepatosplenic form of schistosomiasis in an endemic area.

\section{REFERENCES}

Andrade ZA, Sadigursky M, Gomes LS 1978. Hepatite crônica ativa e esquistossomose descompensada. Rev Ass Med Bras 24: 366-368.

Bassily S, Dunn MA, Farid Z, Kilpatrick ME, El-Masry NA, Kamel IA, El-Alamy M, Murphy BL 1983. Chronic hepatitis B in patients with schistosomiasis mansoni. Am J Trop Med Hyg 86: 67-71.

Bassily S, Farid Z, Higashi GI, Kamel IA, El-Masry NA, Watten RH 1979. Chronic hepatitis B antigenaemia in patients with hepatosplenic schistosomiasis. $A m$ J Trop Med Hyg 82: 248-251.

CNE/FNS/MS - Centro Nacional de Epidemiologia, Fundação Nacional de Saúde, Ministério da Saúde 1996. Proposta de Vacinação da Hepatite B. Bol Epidemiol 1: 12.

Coelho HSM, Fogaça HS, Hércules HC, Carneiro AJV, Lemme EMO, Toledo JA 1985. Hepatite crônica associada à esquistossomose hepatoesplênica. Estudo clínico-evolutivo de 19 casos. GED 4: 41-44.

Coltorti M, Del Vecchio BC, Caporaso N 1984. Familial clustering of HBV infection and chronic liver disease. Front Gastrointest Res 8: 169-179.

Daneshemend TK, Homeida M, Satir AA, Vandervelde EM 1984. Increased hepatitis B infection in hepatosplenic schistosomiasis in the Sudan. East African Med J 61: 133-135.

Darwish MA, Shaker M, Raslan O, Raouf TA 1992. Hepatitis B and D viral infections among schistosomal patients in Egypt. J Egypt Publ Hlth Assoc 67: 547-563.
Dean JA, Dean AG, Burton A, Dicker R. Epilnfo Version 5 1990. A Word Processing, Database, and Statistics System for Epidemiology on Microcomputer. Georgia, USD Inc, Stone Mountain.

Domingo EO, Lingao AL, Tiu E, Lao JY, Olveda RM 1983. HBV exposure and HBsAg positive rates in schistosomiasis japonica: study in a Philippine community endemic for both infections. Southeast Asian J Trop Med Pub Hlth 14: 456-462.

El-Badrawy N, El-Rooby A, Hunter S, Kamel I, AbdelGawad Z 1983. Association of HBsAg with hepatosplenic schistosomiasis II. A clinic-pathological study of HBsAg and anti-HBs in serum. J Egyp Med Assoc 66: 571-582.

El-Raziky EH, Zakaria S, El-Kalouby AH, Shaker ZA, Ata AA, El-Battawy Y 1979. Prevalence of HBsAg in schistosomiasis. (A) General aspects. Egypt J Bilharziasis 6: 1-10.

Eltoum IA, Ghalib HW, A-Gadir AF, Suliaman SM, Homeida MMA 1991. Lack of association between schistosomiasis and hepatitis B virus infection in Gezira-Managil area, Sudan. Trans $R$ Soc Trop Med Hyg 85: 81-82.

Farghaly AG, Barakat RMR 1992. Association between chronic hepatitis B carrier state and schistosomiasis. J Egypt Publ Hlth Assoc 67: 607-621.

Franks AL, Berg CJ, Kane MA, Browne BB, Sikes RK, Elsea WR, Burton AH 1989. Hepatitis B virus infection among children born in the United States to Southeast Asian refugees. N Engl J Med 321: 1301-1305.

Gerspacher-Lara R, Pinto da Silva R, Rayes AAM, Drummond SC, Lambertucci JR 1997. Ultrasonography of periportal fibrosis in schistosomiasis mansoni in Brazil. Trans R Soc Trop Med Hyg 91: 307-9.

Ghaffar YA, Fattah SA, Kamel M, Badr RM, Mahomed FF, Strickland GT 1991. The impact of endemic schistosomiasis on acute viral hepatitis. Am J Trop Med Hyg 45: 743-750.

Guimarães RX 1973. Frequência de Antígeno Austrália em Indivíduos Normais, Índios do Parque Nacional do Xingú e Portadores de Esquistossomose Mansônica, Thesis, Escola Paulista de Medicina, São Paulo, SP, 153 pp.

Guimarães RX, Silva EC, Nigro SP, Kimura RT, Takeda A, Almeida FMR 1981. Sistemas antigênicos da hepatite B na esquistossomose mansônica. Arq Gastroenterol 18: 145-151.

Hammad HA, El-Fattah MMZ, Moris M, Madina EH, El-Abbasy AA, Soliman ATM 1990. Study on some hepatic functions and prevalence of hepatitis B surface antigenaemia in Egyptian children with schistosomal hepatic fibrosis. J Trop Pediatr 36: 126-127.

Hanley JA, McNeill BJ 1982. The meaning and use of the area under a Receiver Operating Characteristic (ROC) curve. Radiology 143: 29-36.

Hunter S, El-Badrawy, Kamel I, Khalil S, Hammam S, El-Rooby A 1983. Association of HBsAg with hepatosplenic schistosomiasis I - Relation of HBsAg in liver cells, to histophatological diagnosis of liver biopsy. J Egypt Med Assoc 66: 559-570.

Hurie MB, Mast EE, Davis JP 1992. Horizontal trans- 
mission of hepatitis B virus infection to United States-born children of Hmong refugees. Pediatrics 89: 269-273.

Hyams KC, El Alamy MA, Pazzaglia G, El Ghorab NM, Sidhom O, Habib M, Dunn MA 1986. Risk of hepatitis B infection among Egyptians infected with Schistosoma mansoni. Am J Trop Med Hyg 35: 10351039.

Johnson RA, Wichern DW 1992. Applied Multivariate Statistical Analysis, 3rd ed., New Jersey, PrenticeHall, 692 pp.

Katz N, Chaves A, Pellegrino J 1972. A simple device for quantitative stool thick-smear technique in schistosomiasis mansoni. Rev Inst Med Trop São Paulo 14: 397-400.

Lambertucci JR 1993. Schistosoma mansoni: pathological and clinical aspects, p.195-225. In Jordan P, Webbe G, Sturrock RF (eds), Human Schistosomiasis, Cab International, Wallingford.

Lambertucci JR, Gerspacher-Lara R, Pinto da Silva RA, Barbosa MM, Teixeira R, Barbosa HF, Serufo JC, Rezende DF, Drummond SC, Rayes AAM 1996. O projeto Queixadinha: a morbidade e o controle da esquistossomose em área endêmica no nordeste de Minas Gerais, Brasil. Rev Soc Bras Med Trop 29: 127-135.

Leichtner AM, Leclair J, Goldman DA, Shumacher RT, Gewolb IH, Katz AJ 1981. Horizontal nonparenteral spread of hepatitis B among children. Ann Int Med 94: 346-349.

Lins ALGP 1993. Contribuição ao Estudo dos Marcadores Sorológicos das Hepatites $B$ e $C$ na Esquistossomose Mansônica, Thesis, Faculdade de Medicina, Universidade de São Paulo, São Paulo, $150 \mathrm{pp}$.

Lyra LGC 1975. Antígeno Austrália na Esquistossomose Mansônica Forma Hepatoesplênica, Thesis. Faculdade de Medicina, Universidade Federal da Bahia, Salvador, 115 pp.

Lyra LGC, Rebouças G, Andrade ZA 1976. Hepatitis B surface antigen carrier state in hepatosplenic schistosomiasis. Gastroenterology 71: 641-645.
Norusis MJ 1992. SPSS/PC+ Advanced Statistics: version 5.0, Chicago, SPSS Inc., 546 pp.

Pereira LMMB, Melo MCV, Lacerda C, Spinelli V, Domingues ALC, Massarolo P, Mies S, Saleh MG, McFarlane IG, Williams R 1994. Hepatitis B virus infection in schistosomiasis mansoni. J Med Virol 42: 203-206.

Pinto-Silva RA, Abrantes WL, Antunes CMF, Lambertucci JR 1994. Sonographic features of portal hypertension in schistosomiasis mansoni. Rev Inst Med Trop São Paulo 36: 355-361.

Rosenberg HK, Markowitz RI, Kolberg, H, Park C, Hubbard A, Bellah RD 1991. Normal splenic size in infants and children: Sonographic measurements. Am Roentgen Ray Soc 157: 119-121.

Serufo JC 1997. A Associação entre a Hepatite B e a Esquistossomose Mansônica: uma Falácia Ecológica, Thesis, Faculdade de Medicina, Universidade Federal de Minas Gerais, 204 pp.

Serufo JC, Lambertucci JR 1997. Esquistossomose e hepatites virais: uma revisão. Rev Soc Bras Med Trop 30: 313-322.

Serufo JC, Pinto da Silva RA, Gerspacher-Lara R, Teixeira R, Santos SG, Lambertucci JR 1996. Alta prevalência da hepatite $\mathrm{B}$ em área endêmica de esquistossomose. Rev Soc Bras Med Trop 28 (suppl 1): 106.

Strauss E, Gayotto LCC, Lacet CM, Caly WR, Bellesa MAO, Silva LC, Valentim JF, Ribeiro LT, Vasconcelos MCL, Fukushima J 1988. Hepatitis B virus and mansonic schistosomiasis: a non-specific association. Hepatology 8: 1330.

Van der Borch CA 1987. The association of chronic hepatitis B infection with chronic schistosomiasis mansoni in Kenya. East Afr Med J 64: 95-101.

WHO-World Health Organization 1991. Meeting on ultrasonography in schistosomiasis: Proposal for a practical guide to the standardized use of ultrasonography in the assessment of pathological changes. Cairo, WHO, 32 pp.

Zuckerman AJ 1985. Controversies in immunization against hepatitis B. Hepatology 5: 1227-1230. 
